\title{
APLIKASI AUGMENTED REALITY ISTANA KERAJAAN KASEPUHAN DAN KANOMAN CIREBON BERBASIS ANDROID
}

\author{
Mohamad Saefudin \\ Program Studi Sistem Informasi \\ STMIK JAKARTA STI\&K \\ Email: saefudin@gmail.com \\ Normalisa \\ Fakultas Teknik, Program Studi Teknik Informatika \\ Universitas Pamulang \\ Email: lisa.norma@gmail.com
}

\begin{abstract}
ABSTRAK
Ponsel memiliki sebuah sistem operasi dalam penggunaannya, salah satu sistem operasi yang sedang meningkat saat ini adalah Android. Jurnal kali ini mengambil materi pembuatan aplikasi Augmented Reality Berbasis Android. Aplikasi ini berisi Pengenalan Sejarah Kerajaan di Daerah Cirebon dalam bentuk istana kerajaan secara tiga dimensi. Augmented Reality ini dibuat dengan menggunakan Software Unity, sedangkan untuk objek 3Dimensi yang akan ditampilkan pada handphone dibuat dengan Blender 2.69 dan untuk marker dibuat menggunakan Adobe Photoshop yang dimanipulasikan sebagai marker. Dalam penulisan ini dijelaskan mengenai cara membuat objek 3Dimensi yang dibuat dengan Blender 2.69 dan juga tentang cara pembuatan Augmented Reality menggunakan Unity.
\end{abstract}

Kata kunci: cirebon, kasepuhan, kanoman, kerajaan, augmented reality, android.

\begin{abstract}
Mobile phones have an operating system in use, one of the operating systems are on the rise today is Android. Journal writing this time interested in trying to make Android-Based Augmented Reality applications. This application contains Introduction to History of the Kingdom in Cirebon area is in the form of the royal palace in three dimensions. Augmented Reality is created using Unity software, while for 3Dimensi objects to be displayed on mobile phones made with Blender 2.69 and for marker created using Adobe Photoshop CS3 is manipulated as a marker. In this paper explained about how to create objects 3Dimensi made with Blender 2.69 and also the way of making use of Augmented Reality Unity.
\end{abstract}

Keywords: cirebon, kasepuhan, kanoman, kingdom, augmented reality, android.

\section{PENDAHULUAN}

Teknologi komputer saat ini sudah sangat berkembang pesat diberbagai bidang, baik ilmu pengetahuan, pekerjaan, seni, kesehatan, pendidikan, dan budaya. Pemanfaatan teknologi ini dirasakan tidak hanya oleh orang dewasa, melainkan juga anak-anak. Pekerjaan manusia yang dikerjakan sendiri oleh manusia (manual) sudah banyak digantikan oleh komputer. Dengan begitu semua dapat dikerjakan lebih mudah, praktis, mengurangi banyak kesalahan dan hemat waktu.

Indonesia adalah sebuah Negara yang mempunyai sejarah kerajaan yang sangat panjang. Salah satu sejarah tentang kerajaan adalah kerajaan yang bernama yang berada di wilayah Cirebon. Cirebon adalah sebuah kerajaan yang ada di Indonesia dengan pusat kerajaan terletak di Cirebon kota. Situs kerajaan berdiri dengan megahnya sebuah Istana yang menjadi pusat dari semua kegiatan dan pemerintahan Kerajaan Cirebon. Istana ini adalah jantung dari kerajaan Cirebon, disini tempat diadakan pertemuanpertemuan antara Raja dan pejabat untuk membahas semua perkembangan dan situasi dari kerajaan. Teknologi Augmented Reality dan berbasis sistem operasi android adalah dapat menggambarkan kebesaran kemegahan Istana tersebut. Selain itu citra yang akan dibuat adalah dalam bentuk 3 dimensi, sehingga lebih menarik dan lebih nyata. [1].

Augmented Reality merupakan ilmu digital yang mempelajari tentang cara menyatukan objek yang bersifat maya atau semu ke dalam dunia nyata kemudian mengimplementasikannya pada waktu yang bersamaan. Augmented Reality memproses visualisasi dan penyampaian informasi dengan lebih variatif. Informasi tidak hanya dapat disajikan secara 2D tapi juga dapat dengan 3D. Selain menggunakan 
Augmented Reality aplikasi ini juga dibantu dengan menggunakan sistem operasi Android. Android adalah sistem operasi pada handphone yang saat ini banyak digunakan pada jenis smartphone dan berbasis open source atau dapat dikembangkan dengan bebas. Melalui Android objek 3D akan ditampilkan, sistem operasi Android mendukung adanya gambar, suara dan animasi bergerak.

Diharapkan aplikasi ini dapat membantu masyarakat terutama para pelajar sekolah untuk lebih mengenal sejarah kemegahan kerajaan Cirebon, sehingga masyarakat akan lebih bangga pada sejarahsejarah Negara Indonesia.

Pembuatan Aplikasi Augmented Reality Istana Kerajaan Cirebon menggunakan Unity[4] berbasis Android. Untuk menampilkan objek akan digunakan marker. Objek Augmented Reality yang akan ditampilkan nantinya dibatasi menjadi 5 objek bangunan atau situs yang ada didalam istana Kerajaan Cirebon tersebut. Aplikasi ini juga akan diberi laar belakang musik instrument. Pembuatan model objek akan dibuat dengan menggunakan Blender, sedangkan untuk pembuatan Augmented Reality menggunakan Unity [4]3D. Aplikasi ini akan ditampilkan pada handphone Android dengan spesifikasi khusus. [5]

\section{METODOLOGI PENELITIAN}

Ada beberapa metode dalam penulisan ini, diantaranya:

a. Mengumpulkan data-data yang berkaitan dengan penelitian pembuatan aplikasi ini menggunakan metode pengamatan melalui media internet, mempelajari tentang Istana Kerajaan Cirebon dengan mambaca buku, mempelajari cara menggunakan software Blender untuk membuat modeling objek serta mempelajari software Unity [4]3D untuk membuat marker.[4]

b. Melakukan tahap analisa dengan menguji peralatan yang dibutuhkan untuk membuat aplikasi Augmented dan Virtual reality ini. Software yang digunakan adalah Blender dan Unity [4] 3D. Blender merupakan software tiga dimensi yang dapat membuat objek tampak realistis. Sedangkan Unity[4]3D adalah software develop game yang digunakan untuk menampilkan aplikasi Augmented Reality pada sebuah marker.[4]

c. Tahap perancangan aplikasi menggunakan tools $U M L$ untuk menjelaskan tahap-tahap pembuatannya.

d. Pembuatan objek 3 dimensi dengan menggunakan Blender 3d. Pembuatan marker dan pembuatan program android agar aplikasi bisa dijalankan di sistem operasi android.

e. Melakukan pengujian dengan menjalankan aplikasi Augmented Reality ini serta melakukan pengujian pada user dengan cara membuat kusioner.

\section{HASIL PENELITIAN DAN PEMBAHASAN}

Pada bagian ini dilakukan proses perancangan Augmented Reality. Perancangannya memerlukan beberapa tahapannya diantaranya: rancangan aplikasi rekontruksi berbasis Android, uml program, membuat marker, dan membuat program. Objek yang akan ditampilkan pada aplikasi ini adalah objek 3D bangunan Istana dan beberapa situs peninggalan Kerajaan Cirebon.

\subsection{Perancangan Aplikasi}

Rancangan aplikasi Augmented Reality yang bisa menampilkan objek 3D bangunan Istana dan tempat ibadah dengan menggunakan mobile phone Android. Aplikasi ini diharapkan penggunanya dapat melihat kemegahan istana kerajaan.

Aplikasi ini dapat menampilkan beberapa objek 3D. Bangunan Istana dan bebrapa situs tersebut dapat ditampilkan sesuai dengan keinginan penggunanya dengan menggunakan beberapa marker sebagai media pendukung.

Rancangan pembuatan objek 3D yang dibutuhkan dengan menggunakan Blender 2.64 dan tool pendukung untuk Augmented Reality. Pengumpulan data berupa gambar, penjelasan, artikel, maupun jurnal dari internet yang berkaitan dengan aplikasi Augmented Reality. Aplikasi ini dibuat dengan menggunakan bahasa pemrograman C\# (dibaca : C Sharp) dan JavaScript untuk Augmented Reality. [6]

\subsection{Use Case dan Activity Diagram}

Use Case diagram adalah sebuah diagram untuk menggambarkan hubungan antara pemakai dengan sistem. Berikut ini adalah gambar Use Case Diagram yang menggambarkan aktivitas yang dilakukan oleh pengguna terhadap aplikasi seperti terlihat pada gambar 1.[3] 


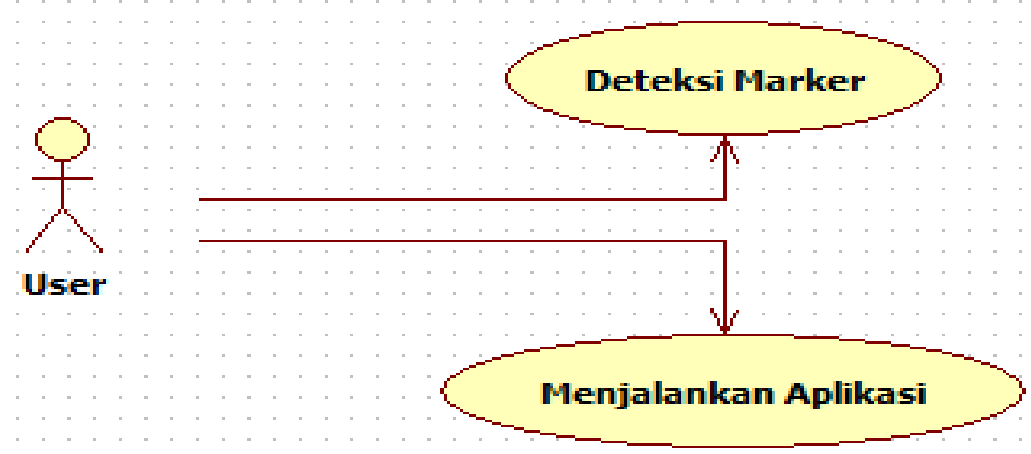

Gambar 1. Use Case Diagram

Setelah use case diagram, ada lagi Diagram Activity, diagram ini menunjukkan penggunaan aplikasi oleh pengguna, dan proses berjalannya aplikasi pada sistem. Berikut ini adalah gambar Diagram Aktifitas yang menggambarkan aktifitas yang dilakukan pengguna terhadap aplikasi Augmented Reality tentang objek istana kerajaan Kasepuhan dan Kanoman Cirebon. Seperti terlihat pada Gambar 2.[3]

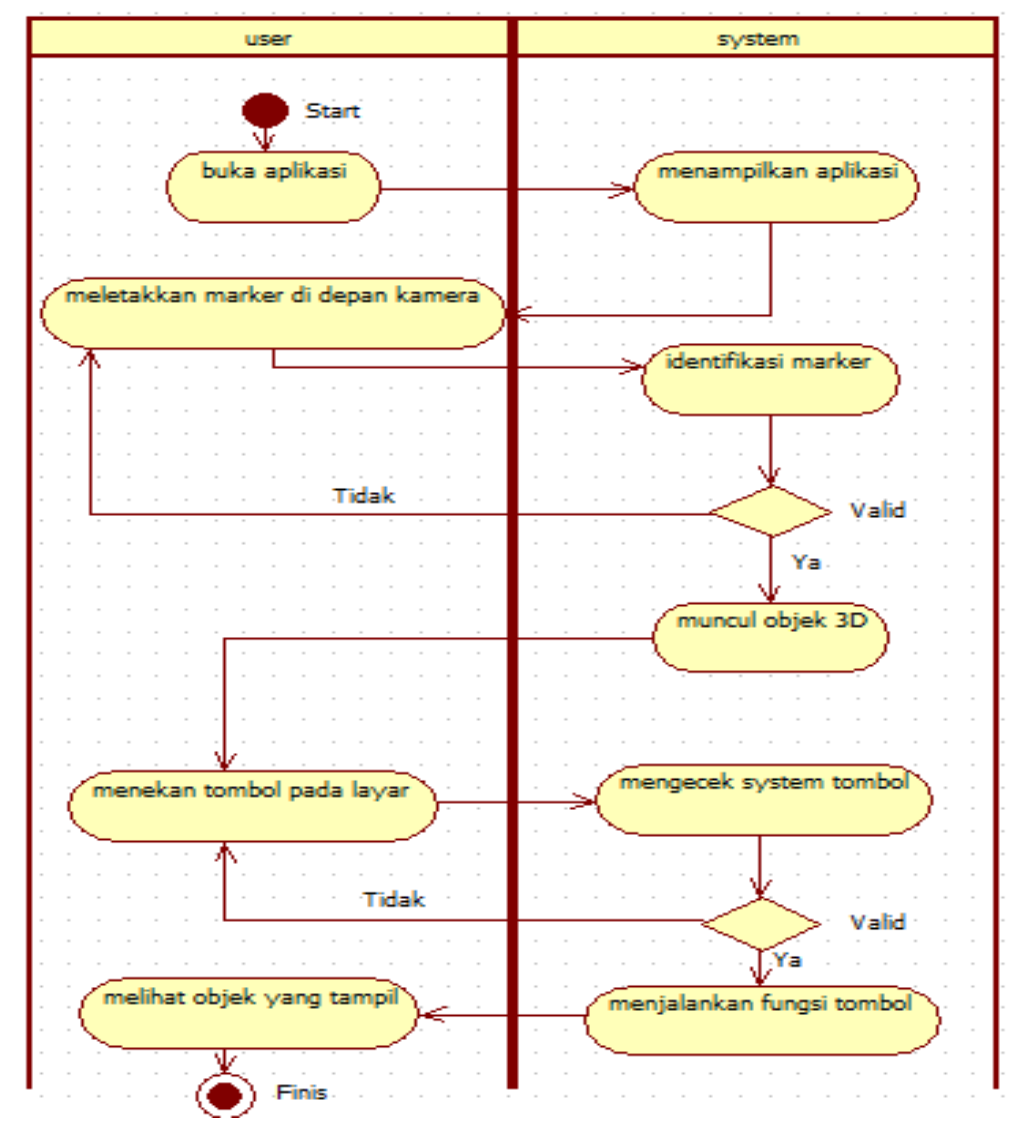

Gambar 2. Activity Diagram Aplikasi

\subsection{Struktur Navigasi}

Struktur Navigasi dapat dikatakan sebagai penggambar dari hubungan atau rantai kerja dari seluruh element yang akan digunakan dalam aplikasi. Aplikasi menggunakan Struktur Navigasi Hirarki. Berikut ini adalah rancangan Navigasi Menu Aplikasi seperti terlihat pada Gambar 3. 


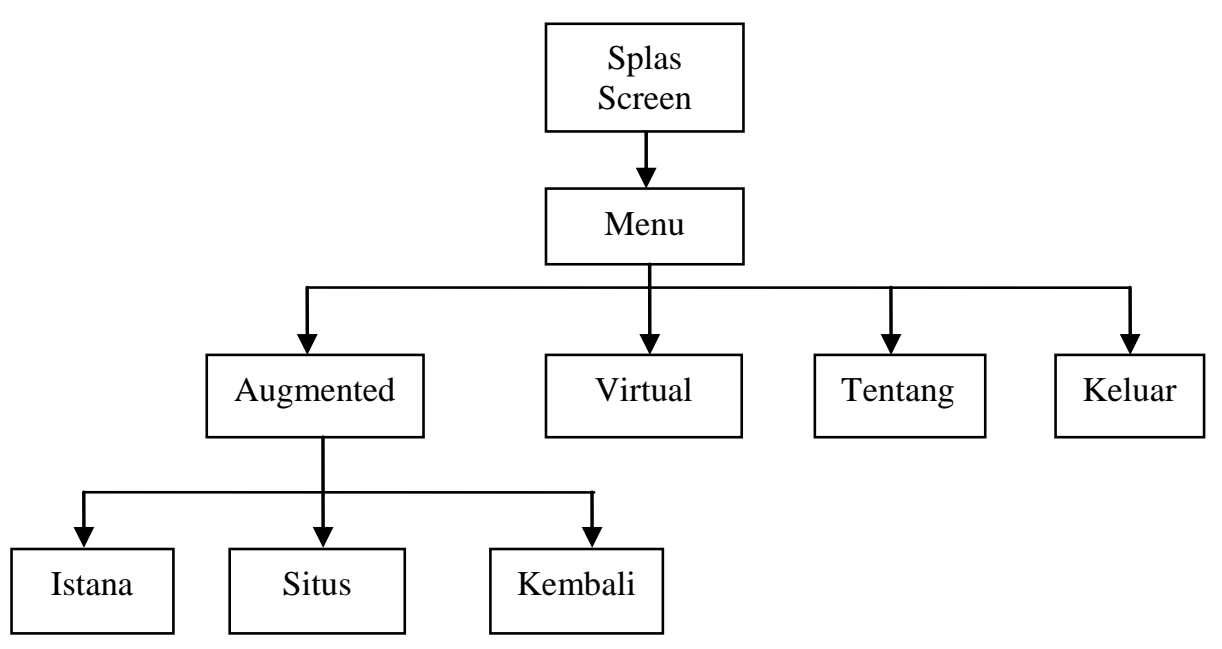

Gambar 3. Struktur Navigasi

\subsection{Rancangan Tampilan}

Perancangan tampilan aplikasi ini sangat dilakukan terdiri dari perancangan menu, perancangan marker, dan perancangan tampilan bangunan-bangunan istana.

\subsubsection{Rancangan Tampilan Menu}

Rancangan tampilan menu aplikasi ini merupakan rancangan tampilan yang terdapat pada menu utama, Ada beberapa macam menu yang dapat digunakan oleh pengguna pada tampilan tersebut. Berikut ini adalah rancangan tampilannya menu navigasi aplikasi seperti terlihat pada Gambar 4.

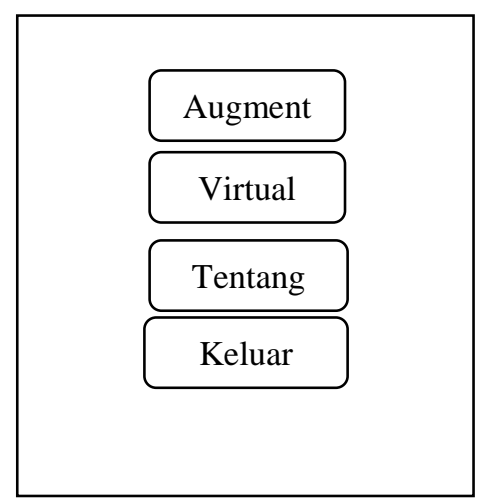

\section{Gambar 4. Rancangan Tampilan Menu}

Penjelasan rancangan tampilan menu aplikasi Augmented Reality adalah sebagai berikut :

a. Augmented, Yaitu tampilan objek 3D Augmented Reality bangunan Istana.

b. Virtual, Yaitu tampilan objek 3D Virtual Reality bangunan Istana.

c. Tentang, Yaitu keterangan tentang pengembang atau pembuat.

d. Keluar, Yaitu menu untuk keluar dari aplikasi AR ini.

\subsubsection{Rancangan Marker}

Pembuatan marker Bangunan Istana Kerajaan Cirebon dalam bentuk brosur untuk mendukung aplikasi Augmented Reality ini. Marker sebagai penanda khusus disatukan dalam sebuah katalog, sehingga pengguna dapat langsung melihat tampilan objek 3D Augmented Reality. Berikut adalah rancangan Marker seperti terlihat pada Gambar 5. 


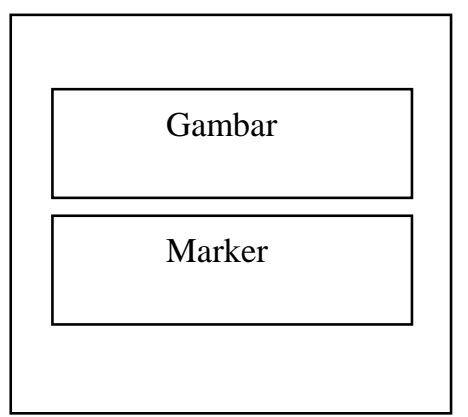

\section{Gambar 5. Rancangan Tampilan Marker}

\subsubsection{Rancangan Tampilan Augmented Reality}

Setelah pengguna melihat halaman awal splash screen, selanjutnya akan masuk kedalam menu utama, dimana disini tampilan Augmented Reality akan muncul. Pengguna sudah bisa untuk menggunakan aplikasi ini dengan menyorotkan kamera pada handphone ke marker. Berikut adalah rancangan gambar Augmenter Reality seperti pada Gambar 6.

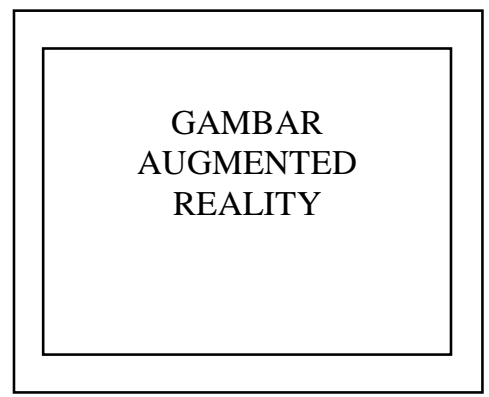

\section{Gambar 6. Rancangan Tampilan Augmented Reality}

Penjelasan rancangan tampilan augmented reality tersebut adalah sebagai berikut : Augmented Reality Yaitu objek 3D bangunan Istana yang akan muncul apabila kamera pada handphone disorotkan pada marker.

\subsubsection{Rancangan Tampilan Virtual}

Tampilan ini merupakan halaman yang akan muncul apabila pengguna memilih menu help. Pada halaman ini, pengguna dapat mengetahui dan melihat tata cara menggunakan aplikasi Augmented Reality ini. Berikut ini adalah rancangan tampilannya seperti pada Gambar 7:

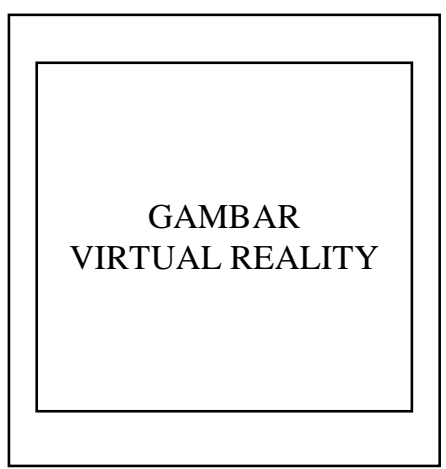

\section{Gambar 7. Rancangan Tampilan Virtual}

\subsubsection{Pembuatan Objek}

Pada pembuatan objek 3D Augmented Reality Istana Kerajaan Cirebon dibuat dengan menggunakan software pendukung Blender 2.64.[7] Berikut ini adalah tampilan dari interface atau antarmuka software Blander 3.64 yang digunakan untuk merancang objek istana terlihat seperti pada Gambar 8 . 


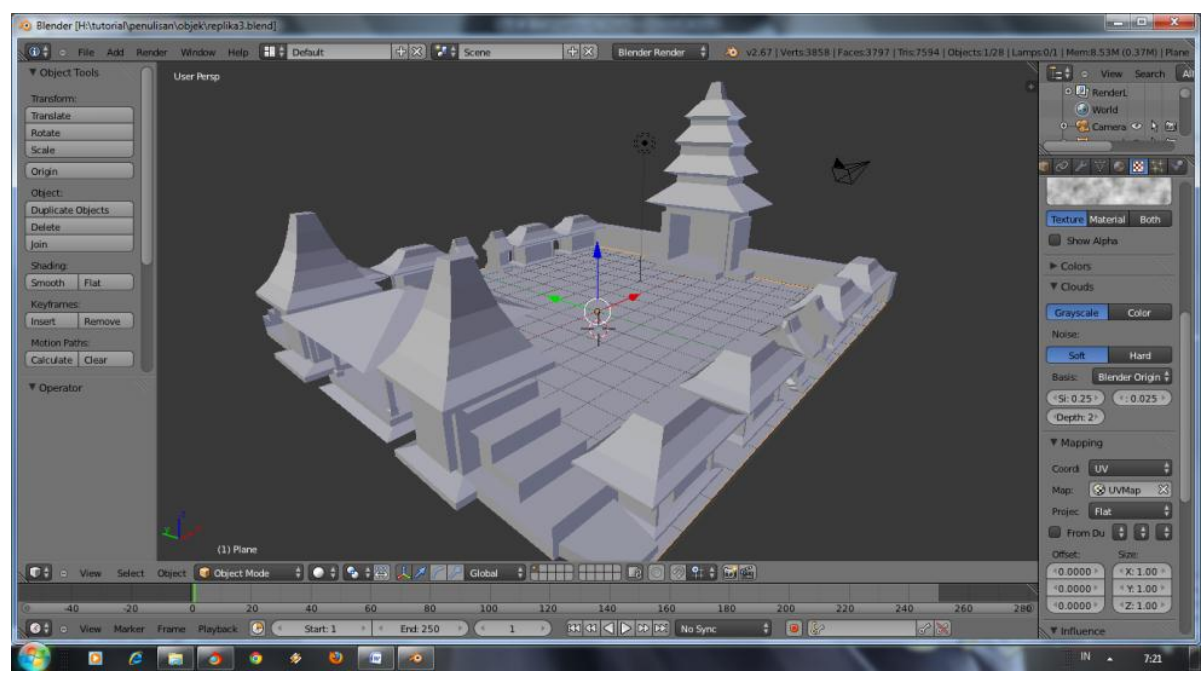

Gambar 8. Pembuatan Objek Bangunan

\subsubsection{Pembuatan Marker}

Marker adalah suatu penanda yang membuat objek 3D tampil pada tampilan kertas di layar handphone. Pembuatan marker dengan menggunakan Adobe Photoshop. [9] Apabila ingin membuat aplikasi tersebut maka dapat menggunakan gambar yang ada. Marker yang sudah didesain kemudian diupload situs http://developer.vuforia.com. [10]

\subsubsection{Pembuatan Program}

Pembuatan aplikasi Augmented Reality dengan menggunakan tool Unity [4] 3D. Sebelum membuat aplikasi Augmented Reality ini, terlebih dahulu melakukan instalasi software-software pendukungnya seperti Android SDK, plugin Android dan Unity [4] 3D. Berikut ini adalah hasil gambaran dari desain objek tentang istana kerajaan yang dibuat menggunakan Software Blander 2.64 [7] terlihat pada Gambar 9.

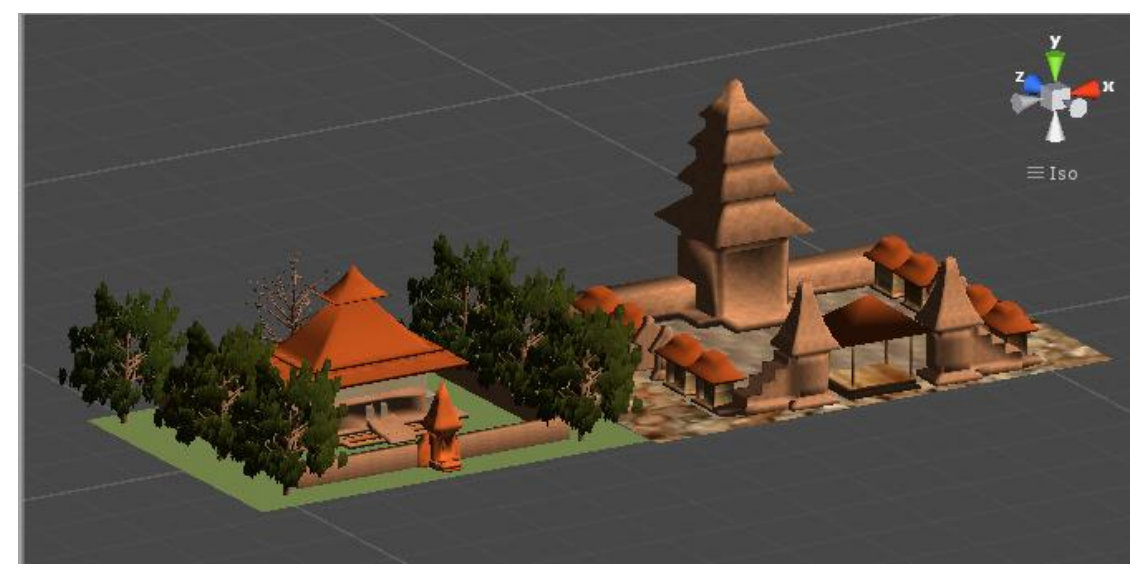

Gambar 9. Objek 3D

\subsubsection{Hasil Survey Pengguna}

Berikut ini adalah table hasil dari survai penelitian yang dilakukan kepada para responden yang di pilih secara acak. Berdasarkan hasil survai penelitian ini secara garis besar responden membeikan nilai positif terhadap aplikasi yang di kembangkan. Nilai kekurangan dari hasil survai ini akan dievaluasi lagi dan dijadikan acuan untuk perbaikan secara jelas terlihat pada Tabel 1. 
Tabel 1. Tabel Pertanyaan

\begin{tabular}{clccc}
\hline No & \multicolumn{1}{c}{ Item Pertanyaan } & Skor & Persentase & Kategori \\
\hline 1. & Apakah aplikasi berjalan dengan baik? & 70 & 100 & Baik \\
2. & Apakah aplikasi mudah dimengerti? & 59 & 84.61 & Baik \\
3. & Apakah desain interface aplikasi ini menarik? & 53 & 76.92 & Baik \\
$\begin{array}{l}\text { Apakah aplikasi ini dapat meningkatkan pengetahuan } \\
\text { sejarah? }\end{array}$ & 53 & 76.92 & Baik \\
$\begin{array}{l}\text { Apakah aplikasi ini meningkatkan minat anak belajar } \\
\text { sejarah? }\end{array}$ & 64 & 92.30 & Baik \\
$\begin{array}{l}\text { Apakah dengan aplikasi ini anak-anak dapat mengetahui } \\
\text { tentang kerajaan Cirebon? }\end{array}$ & 59 & 84.61 & Baik \\
$\begin{array}{l}\text { Apakah aplikasi ini mempermudah pembelajaran anak } \\
\text { tentang sejarah? }\end{array}$ & 37 & 54.84 & Kurang \\
& $\quad$ Jumlah & $\mathbf{3 9 5}$ & $\mathbf{5 7 0 . 2}$ & Baik \\
& $\mathbf{5 6 . 4 2}$ & $\mathbf{8 0 . 6}$ & Baik \\
\hline
\end{tabular}

Rekapitulasi hasil jawaban responden dari tabel diatas, didapat dari perhitungan sebagai berikut:

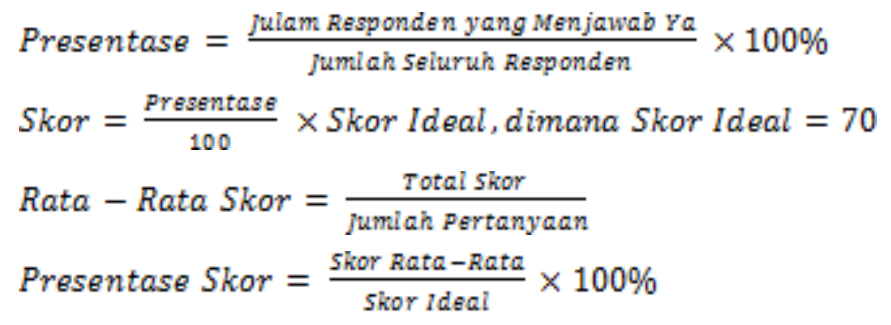

Kategori dari persentase yang telah dihitung, dimasukkan kedalam Kategori, yaitu:

Tabel 2. Kategori Persentase

\begin{tabular}{cc}
\hline Keterangan & Rata-rata nilai \\
\hline Baik & $76 \%-100 \%$ \\
Cukup & $56 \%-75 \%$ \\
Kurang Baik & $40 \%-55 \%$ \\
Tidak Baik & Kurang dari $40 \%$ \\
\hline
\end{tabular}

Table kategori diatas adalah menyatakan bahwa: Jika Nilai total rata-tata hasil perhitungan bernilai 76 sampai 100 maka hasil survai menyatakan bahwa responden memberikan nilai B AIK. Jika Nilai total rata-tata hasil perhitungan bernilai 56 sampai 75 maka hasil survai menyatakan bahwa responden memberikan nilai CUKUP.

Jika Nilai total rata-tata hasil perhitungan bernilai 40 sampai 55 maka hasil survai menyatakan bahwa responden memberikan nilai KURANG BAIK. Jika Nilai total rata-tata hasil perhitungan bernilai dibawah 40 maka hasil survai menyatakan bahwa responden memberikan nilai TIDAK BAIK.

Berikut ini adalah beberapa kesimpulan dari pembuatan aplikasi ini. Dari 13 orang responden pengguna, telah menjawab dan diperoleh hasil sebanyak $80.60 \%$ menjawab bahwa aplikasi ini.
a. Berjalan dengan baik
b. Mudah dimengerti
c. Desain interface yang menarik
d. Dapat meningkatkan pengetahuan anak-anak
e. Dapat meningkatkan minat anak-anak untuk belajar sejarah

\section{KESIMPULAN}

Hasil Penulisan Ilmiah ini adalah aplikasi Augmented sederhana untuk pengenalan Istana Kerajaan Cirebon menggunakan sistem operasi Android. Aplikasi ini tentunya dapat membantu untuk lebih mengenal sejarah dari Kerajaan Cirebon yang dulu pernah ada di wilayah nusantara. Aplikasi ini dapat 
dikembangkan untuk kasus yang sama tentang rekontruksi kerajaan-kerajaan yang pernah ada di Nusantara. Banyak sejarah kerajaan-kerajaan di Nusantara yang keberadaannya sudah tidak diketahui lagi dimana lokasi dan peninggalannya.

\section{DAFTAR PUSTAKA}

[1] Carolina Dinda. Aplikasi Berbasis Android Menggunakan Teknologi Augmented Reality. Penelitian Ilmiah Jurusan Teknik Informatika Universitas Gunadarma. 2013

[2] Kukuh Irawan Aristanto, Buku Interaktif Augmented dan Virtual Reality Rekontruksi 3D Istana Majapahit, Universitas Gunadarma 2014

[3] Irwanto dan Djon, Perancangan Objek Oriented Software dengan UML, Andy Publisher, Jakarta, 2008.

[4] Muhammad Ichsan, Membuat Game 3D Berbasis Web Menggunakan Unity, Interactify Publishing, Jakarta, 2011.

[5] Safaat H. "Pemrograman Aplikasi Mobile Smartphone dan Tablet PC Berbasis Android". Jakarta:Informatika. 2010.

[6] Potts, Steve dan Clayton Walnum. “Dasar-Dasar Pemrograman C\#”. Yogyakarta: Andi. 2001.

[7] Wartmann, Carsten, Panduan Lengkap Menggunakan Blender, Elex Media Komputindo, Jakarta, 2004.

[8] Tim James Dearsley, "The Original Augmented Reality for The Real Estate App", http://www.jamesdearsley.co.uk/augmented-reality/the-original-augmented-reality-for-real-estateapp/, 2013, Tanggal Akses: 8 Mei 2014

[9] Tim Vuforia, "Forums", https://developer.vuforia.com/forum, 2013, Tanggal Akses: 27 juni 2014. 